\title{
S ] НАЛОГООБЛОЖЕНИЕ ПРИРОВОПОЛЬЗОВАНИЯ
}

Агузарова Ф.С., Татрова Э.Т.

\section{ВЛИЯНИЕ НЕФТЕГАЗОВЫХ ДОХОДОВ НА ФОРМИРОВАНИЕ ФЕДЕРАЛЬНОГО БЮДЖЕТА РОССИЙСКОЙ ФЕДЕРАЦИИ}

Аннотация: В статье «Влияние нефтегазовых доходов на формирование федерального бюджета Российской Федерации» поднимается серьезная проблема нефтегазовых доходов, выявляется их существенное влияние на формирование федерального бюджета. Более того, доказывается большая зависимость от указанных сырьевых ресурсов в стране. Предлагается создание бюджетных резервов для ухода от высокой зависимости нефтегазовых поступлений. В современной России природные ресурсы используются недостаточно эффективно. Интересы государства не всегда защищены. В свою очередь, y пользователей (предпринимателей) природных ресурсов отсутствуют стимульк $к$ рациональному их использованию, так как их основной целью выступает получение прибыли. Авторы провели анализ нефтегазовых доходов в федеральном бюджете Российской Федерации за 2010-2012 г2., выделив их роль в числе налоговых доходов. Анализ показал, в числе налогов в системе природопользования центральное место занимает налог на добычу полезных ископаемых. Все это обуславливает актуальность данной проблематики. Review: In this article the authors raise an important issue of oil and gas income and their considerable influence upon the formation of the federal budget. Moreover, the authors prove considerable dependency on the raw resources in Russia. The authors offer to form budgetary reserve to avoid substantive dependency on oil and gas income. Currently the natural resources are not used efficiently in Russia. The interests of the state are not always being protected. At the same time the consumers (entrepreneurs) of natural resources lack the stimulate for the rational use, since their main goal is to gain profit. The authors analyzed oil and gas income into the federal budget of the Russian Federation in 2010-2012, and singled out their role in tax income. The analysis has shown that the tax on mining of natural resources has the largest share, proving topicality of the issue.

Ключевые слова: исчерпаемые ресурсы, рента, добыча полезных ископаемых, полезные ископаемые, нефтегазовые доходы, нефть, природный газ, нефтегазовый комплекс, сырьевой потенциал, рациональное природопользование

Keywords: deplete resources, rent, mining of natural resources, natural resources, oil and gas incomes, oil, natural gas, oil and gas complex, raw materials potential, rational use of natural resources. 


\section{Налоги и налогообложение - №9(111) • 2013}

$\Pi$

риродный газ и нефть являются самыми ценными компонентами сырьевой базы всей добывающей индустрии Российской Федерации. Влияние нефтегазового комплекса существенно во многих сферах хозяйствования страны и находится в тесной взаимосвязи во всех секторах экономики. Сегодня природные ресурсы используются недостаточно эффективно, без учета фактора исчерпаемости. Интересы государства не всегда защищены должным образом. В свою очередь, у пользователей природных ресурсов отсутствуют стимулы к рациональному их использованию. Все это парализует экономический климат в Российской Федерации, приводит к нестабильности в экономике.

В связи с обеспечением стабилизации и устойчивости экономики России 1 января 2004 года был образован Стабилизационный фонд. Этот фонд создан с целью создания бюджетных резервов, призванных поддержать бюджетную систему от возможных негативных явлений, связанных с резким падением цен на нефть (как в период кризиса 1998 г.). ${ }^{1}$ На пополнение фонда направлялись доходы от экспортной пошлины на нефть и НДПИ на нефть, полученные сверх установленной нормы. Кроме того, фонд обеспечивал сбалансированность федерального бюджета при снижении цены на нефть ниже базовой, тем самым способствовал стабильности экономического развития страны, уменьшению

\footnotetext{
${ }^{1}$ Бюджетного кодекса Российской Федерации. Гл. 13.1. 2004г. [Budget code of the Russian Federation. Ch. 13.1. 2004]; Федеральный закон РФ № 184-Ф3 от 10.12.2003г. «О внесении дополнений в Бюджетный кодекс РФ в части создания Стабилизационного фонда РФ»; Бюджетный кодекс РФ. Гл. 13.1. 2004 г. [The RF Federal law № 184-FZ of 10.12.2003г. «On amending the Budget code of the Russian Federation regarding the creation of the Stabilization Fund of the Russian Federation»; the RF Budget code. Ch. 13.1. 2004].
}

инфляционного давления, снижению неблагоприятных экономических катаклизм. ${ }^{2}$

С 1 января 2008 г. в условиях мирового финансового кризиса Стабилизационный фонд официально прекратил свое существование, был преобразован и разделен на два новых фонда - Резервный фонд и Фонд национального благосостояния.

Преобразование Стабилизационного фонда осуществлялось в рамках перехода к так называемой концепции не нефтегазового бюджета, то есть раздельного планирования и использования не нефтегазовой и нефтегазовой частей бюджетных доходов. Основным элементом предложенной системы был нефтегазовый трансферт - ограничение на предельный объем нефтегазовых доходов (текущих или накопленных), которые ежегодно могут использоваться на текущие бюджетные расходы. ${ }^{3}$

В последствие основные функции Стабилизационного фонда перешли на резервный фонд. В число функций входило, в частности, выполнение государством своих расходных обязательств в случае снижения поступлений нефтегазовых доходов в федеральный бюджет, а также стабильность

\footnotetext{
2 Постановление Правительства РФ от 23.01.2004 № 31 (ред. от 21.05.2007) «Об утверждении Правил перечисления в Стабилизационный фонд Российской Федерации дополнительных доходов федерального бюджета, остатков средств федерального бюджета на начало финансового года и доходов от размещения средств Стабилизационного фонда Российской Федерации». [Resolution of the Government of the Russian Federation from 23.01.2004 № 31 (amended on 21.05.2007) «On approval of the Rules of transfer into the Stabilization Fund of the Russian Federation of additional Federal budget revenues, the rests of means of the Federal budget at the beginning of the financial year and the income from placing funds of the Stabilization Fund of the Russian Federation»]. ${ }^{3}$ Бюджетного кодекса Российской Федерации. Гл. 13.2. 2008г. [Budget code of the Russian Federation. Ch. 13.2. 2008].
} 
экономического развития страны, уменьшая инфляционный уровень. ${ }^{4}$

Что касается второго фонда - Фонда национального благосостояния, то он изначально призван был обеспечить долгосрочную устойчивость пенсионной системы. Для этого предполагалось активно накапливать средства в фонде при условии роста цен на нефть, активно их инвестировать и за счет получаемого инвестиционного дохода финансировать выплаты по программе софинансирования пенсионных накоплений и часть трансферта из федерального бюджета на покрытие дефицита Пенсионного фонда. ${ }^{5}$

Достичь поставленной цели можно было только при очень быстром накоплении средств в фонд и активной инвестиционной стратегии на фоне благоприятных условий на финансовых рынках, но этого не удалось. Весьма низкий уровень инвестиционных доходов (по причине мирового финансового кризиса) по сравнению с реальными потребностями пенсионной системы привел в дальнейшем к приостановлению деятельности фонда в этом направлении. ${ }^{6}$

${ }^{4}$ Постановление Правительства РФ от 29 декабря 2007 г. № 955 «О порядке управления средствами Резервного фонда». [Resolution of the Government of the Russian Federation of December 292007 № 955 «About the order of management of the Reserve Fund»].

${ }^{5}$ Федеральный закон от 26 апреля 2007 г. N 63-Ф3 «О внесении изменений в Бюджетный кодекс Российской Федерации в части регулирования бюджетного процесса и приведении в соответствие с бюджетным законодательством Российской Федерации отдельных законодательных актов Российской Федерации». [Federal law of 26 April 2007 N 63-FZ «On amendments to the Budget code of the Russian Federation in the part of regulation of the budget process and bringing in conformity with the budget legislation of the Russian Federation of individual legislative acts of the Russian Federation»].

6 Лебединская Л. Роль нефтегазовых фондов в России//Вопросы экономики. - 2012. - №3. С. 98-118. [Lebedinskaya L. Role of oil and gas assets in Russia// Voprosy Ekonomiki. - 2012. - №3. P. 98-118].
Следует отметить, что с учетом уроков последнего финансового кризиса в мире (2008 г.) можно утверждать, что бюджетные резервы России действительно необходимы, так как степень зависимости российской экономики от внешнеэкономической конъюнктуры по-прежнему высокая. Более того, кризис показал, что негативное влияние падения цен на нефть не ограничивается снижением нефтегазовых доходов бюджета. Косвенные эффекты от падения цен и внешнеэкономической нестабильности обусловливают экономический спад, который, в свою очередь, вызывает падение и не нефтегазовых доходов бюджета. Именно поэтому за счет средств Резервного фонда пришлось компенсировать дефицит не нефтегазовых доходов.

Согласимся с мнением экспертов, что в ближайшее время необходимо выполнять новые бюджетные правила, - ограничить чрезмерное наращивание расходов в благоприятные периоды и одновременно поддерживать необходимый объем резервов на случай падения цен. ${ }^{7}$

Итак, проведенный нами анализ роли нефтегазовых фондов в Российской Федерации позволяет сделать следующие выводы. Фактическая роль фондов, направленных на стабилизацию экономики, в целом совпадает с поставленными при их создании задачами. Так, поставленная перед фондами цель - повышение бюджетной устойчивости, в целом достигнута. Средства фондов использовали для обеспечения бюджетной устойчивости, например, финансировали дефицит федерального бюджета в период кризиса - в 2009-2011 гг. Однако в данном случае

\footnotetext{
${ }^{7}$ Ермакова Е.А. Перспективы управления нефтегазовыми фондами России//Финансы и кредит. - 2013. - № 23. C. 2-10. [Ermakova E.A. Prospects of oil and gas fundsRussia//the Finance and the credit. - 2013. - № 23. P. 2-10].
} 
DOI: $10.7256 / 1812-8688.2013 .9 .9591$

При цитировании этой статьи сноска на доі обязательна

\section{Налоги и налогообложение - №9(111) • 2013}

первоначальная роль фонда была расширена. Фактически средства фонда использовали для компенсации недобора не нефтегазовых доходов бюджета, а также финансирования дополнительных расходов на поддержку экономики.

Проведем анализ составляющей нефтегазовых доходов федерального бюджета Российской Федерации, отдельно выделив в налоговых и неналоговых поступлениях. Проблемам использования нефтегазовых доходов федерального бюджета РФ и по сей день уделяется еще недостаточно внимания.

Итак, представим анализ нефтегазовых доходов в федеральном бюджете Российской Федерации за 2010-2012 гг., выделив их роль в числе налоговых доходов (Таблица 1). Но прежде отметим, что федеральный бюджет Российской Федерации - центральный элемент бюджетной системы Российской Федерации. Налоговые поступления занимают первостепенное место в системе доходов федерального бюджета Российской Федерации. Причем наиболее значительны именно налоги в системе природопользования. Важно отметить, что среди установленных Налоговым кодексом Российской Федерации федеральных налогов и сборов в федеральный бюджет зачисляется лишь определенная часть, не исключение налоги за пользование природными ресурсами. Пропорции их распределения устанавливаются в законодательном порядке между бюджетами разных уровней бюджетной системы Российской Федерации не менее трех лет при условии возможного увеличения нормативов отчислений в бюджеты нижестоящего уровня на очередной финансовый период. ${ }^{8}$

Таблицча 1

Нефтегазовые налоговые доходы федерального бюджета Российской Федерации за 2010-2012 ге. (млрд.руб.)

\begin{tabular}{|l|c|c|c|}
\hline \multicolumn{1}{|c|}{ Наименование показателя } & $\mathbf{2 0 1 0}$ г. & $\mathbf{2 0 1 1}$ г. & $\mathbf{2 0 1 2}$ г. \\
\hline $\begin{array}{l}\text { Налоговые доходы } \\
\text { в том числе: }\end{array}$ & 4401,9 & 5985,3 & 6846,4 \\
\hline $\begin{array}{l}\text { Нефтегазовые налоговые доходы (налог на добычу полезных } \\
\text { ископаемых) }\end{array}$ & $\mathbf{1 3 7 6 , 6}$ & $\mathbf{2 0 0 7 , 8}$ & $\mathbf{2 4 2 0 , 5}$ \\
\hline $\begin{array}{l}\text { Налог на добычу полезных ископаемых в виде углеводородного } \\
\text { сырья }\end{array}$ & 1361,2 & 1988,5 & 2399,8 \\
\hline Нефть & 1266,8 & 1845,8 & 2132,6 \\
\hline $\begin{array}{l}\text { Газ горючий природный из всех видов месторождений угле- } \\
\text { водородного сырья }\end{array}$ & 85,1 & 136,3 & 257,4 \\
\hline
\end{tabular}

${ }^{8}$ Бюджетный кодекс Российской Федерации. Гл.7, ст.50. 2013 г. [Budget code of the Russian Federation. Ch. 7, art. 50. 2013].

${ }^{9}$ Налоговый кодекс Российской Федерации. Гл. 26. 2013 г. [Tax code of the Russian Federation. Ch.26. 2013]. 


\begin{tabular}{|c|c|c|c|}
\hline $\begin{array}{l}\text { Газовый конденсат из всех видов месторождений углеводородного } \\
\text { сырья }\end{array}$ & 9,4 & 6,4 & 9,8 \\
\hline $\begin{array}{l}\text { Налог на добычу прочих полезных ископаемых (за исключением } \\
\text { полезных ископаемых в виде природных алмазов) }\end{array}$ & 13,4 & 16,4 & 14,6 \\
\hline $\begin{array}{l}\text { Налог на добычу полезных ископаемых на континентальном } \\
\text { шельфе РФ, в исключительной экономической зоне Российской } \\
\text { Федерации, при добыче полезных ископаемых из недр за } \\
\text { пределами территории Российской Федерации }\end{array}$ & 2,1 & 2,7 & 2,8 \\
\hline $\begin{array}{l}\text { Регулярные платежи за добычу полезных ископаемых (роялти) } \\
\text { при выполнении соглашений о разделе продукции }\end{array}$ & 25,1 & 35,0 & 19,1 \\
\hline $\begin{array}{l}\text { Регулярные платежи за добычу полезных ископаемых (роялти) } \\
\text { при выполнении соглашений о разделе продукции в виде } \\
\text { углеводородного сырья (газ горючий природный) }\end{array}$ & 8,3 & 10,5 & 0,7 \\
\hline $\begin{array}{l}\text { Регулярные платежи за добычу полезных ископаемых (роялти) } \\
\text { при выполнении соглашений о разделе продукции в виде } \\
\text { углеводородного сырья, за исключениемгаза горючего природного }\end{array}$ & 16,8 & 24,6 & 18,4 \\
\hline
\end{tabular}

Источник: Отчетные данные об исполнении федерального бюджета Российской Федерации за 2010-2012 z2.//www.roskazna.ru.

По данным таблицы 1 видно, что в 2010 году общий объем налоговых доходов федерального бюджета составил 4401,9 млрд.руб. Из них нефтегазовые налоговые доходы составили 1376,6 млрд.руб. Так, в их числе львиную долю занимает налог на добычу полезных ископаемых в виде углеводородного сырья 1361,2 млрд.руб. Налог на добычу нефти собран в размере 1266,8 млрд.руб., газа горючего природного из всех видов месторождений углеводородного сырья - 85,1 млрд.руб.

В 2011 году налоговые доходы собраны в размере 5985,3 млрд.руб. Выросли поступления по налогу на добычу полезных ископаемых до 2007,8 млрд.руб. При этом поступления от добычи нефти увеличились до 1845,8 млрд.руб., поступления от газа увеличились до 136,3 млрд.руб.
В 2012 году налоговые доходы выросли до 6846,4 млрд.руб. В их числе нефтегазовым налоговым поступлениям принадлежит 2420,5 млрд.руб., из которых нефтеналоги заняли 2132,6 млрд.руб., а налоги за газ 257,4 млрд.руб.

Таким образом, за 2010-2012 гг. в федеральном бюджете Российской Федерации значительны поступления по нефтегазовым доходам (налог на добычу полезных ископаемых). Их доля составила: в 2010 году $31,2 \%$; в 2011 году - 33,5\%; в 2012 году $35,3 \%$.

На основе данных таблицы 1 изобразим рисунок, где наглядно показана динамика нефтегазовых доходов в сумме налоговых поступлений федерального бюджета РФ за 2010-2012 гг. (Рисунок 1). 


\section{Налоги и налогообложение - №9(111)• 2013}

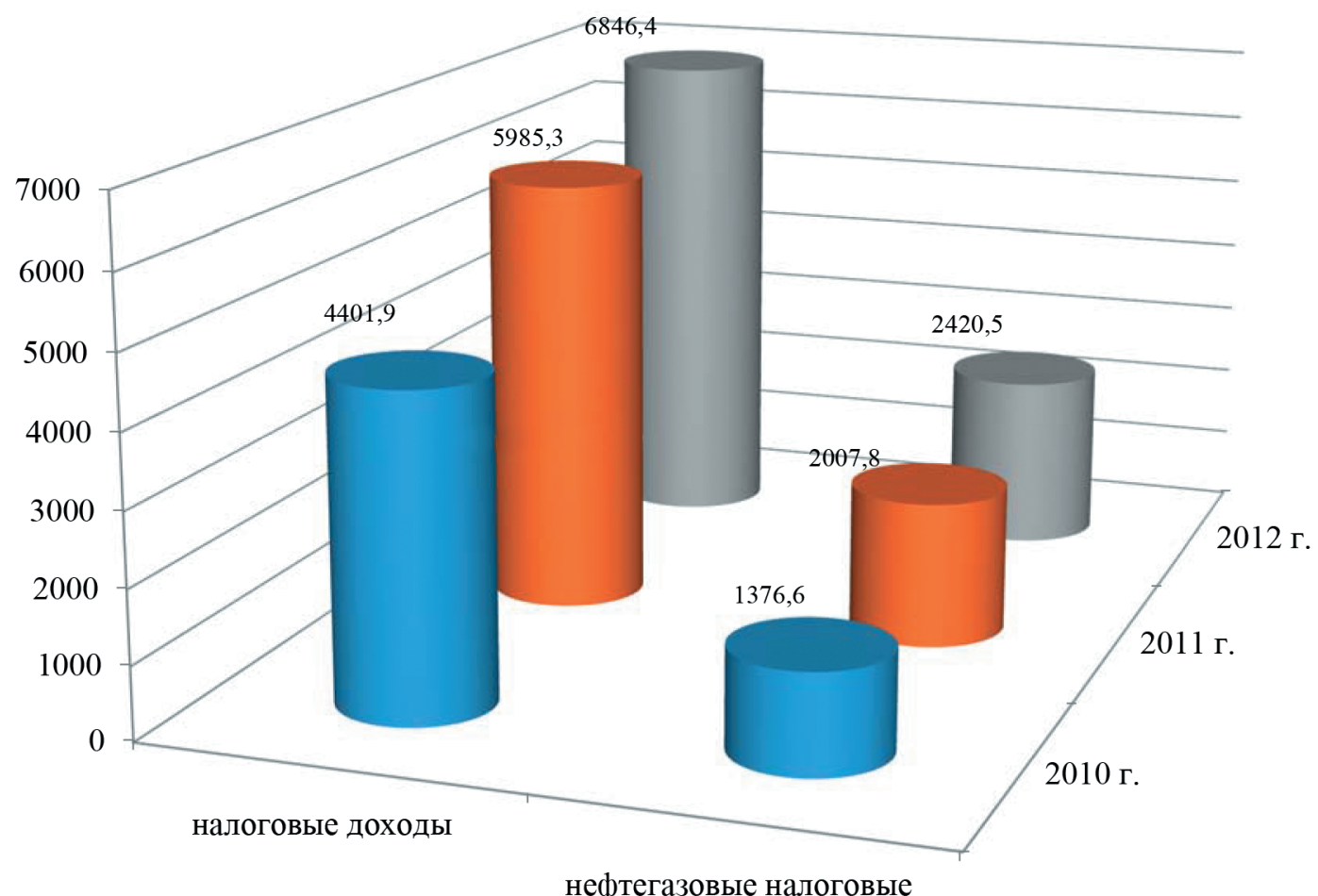

нефтегазовые налоговые

доходы

Рис. 1. Динамика нефтегазовых налоговых доходов в федеральном бюджете Российской Федерации за 2010-2012 г2. (млрд.руб.).

Данные рисунка 1 подчеркивают высокую значимость нефтегазовых поступлений в составе налоговых доходов федерального бюджета Российской Федерации за 20102012 гг. При этом, нефтегазовые налоговые доходы имеют тенденцию к повышению. Наибольший объем поступлений в числе налоговых доходов наблюдается по НДПИ на нефть.

Представим анализ поступления нефтегазовых доходов в федеральном бюджете Российской Федерации за 2010-2012 гг., выделив их роль в числе неналоговых доходов (Таблица 2).

Таблицุа 2

Нефтегазовые неналоговые доходы федерального бюджета Российской Федераџии за 2010-

2012 ге. (млрд.руб.)

\begin{tabular}{|l|c|c|c|}
\hline \multicolumn{1}{|l|}{ Наименование показателя } & $\mathbf{2 0 1 0}$ г. & $\mathbf{2 0 1 1}$ г. & $\mathbf{2 0 1 2}$ г. \\
\hline $\begin{array}{l}\text { Неналоговые доходы } \\
\text { в том числе: }\end{array}$ & 3903,0 & 5352,8 & 5934,5 \\
\hline $\begin{array}{l}\text { Нефтегазовые неналоговые доходы } \\
\text { из них: }\end{array}$ & $\mathbf{2 4 6 9 , 5}$ & $\mathbf{3 6 5 3 , 3}$ & $\mathbf{4 0 5 3 , 1}$ \\
\hline
\end{tabular}




\begin{tabular}{|l|l|l|l|}
\hline Вывозные таможенные пошлины на нефть сырую & 1672,4 & 2332,4 & 2489,6 \\
\hline Вывозные таможенные пошлины на газ природный & 193,3 & 384,4 & 433,5 \\
\hline $\begin{array}{l}\text { Вывозные таможенные пошлины на товары, выработанные из } \\
\text { нефти }\end{array}$ & 603,8 & 936,5 & 1130,0 \\
\hline
\end{tabular}

Источник: Отчетные даннье об исполнении федерального бюджета Российской Федерации за 2010-2012 г2.//www.roskazna.ru.

По данным таблицы 2 видно, что в состав нефтегазовых неналоговых доходов входят: вывозные таможенные пошлины на нефть сырую; вывозные таможенные пошлины на газ природный; вывозные таможенные пошлины на товары, выработанные из нефти.

В 2010 году неналоговые доходы федерального бюджета Российской Федерации исполнены в сумме 3903,0 млрд.руб., из которых нефтегазовые поступления заняли 2469,5 млрд.руб. Из них основной объем поступлений наблюдается по вывозным таможенным пошлинам на нефть сырую 1672,4 млрд.руб. (из 2469,5 млрд.руб.). Что касается вывозных таможенных пошлин на газ природный и на товары, выработанные из нефти, то поступления менее значимы: 193,3 млрд.руб. и 603,8 млрд.руб. соответственно.

В 2011 году неналоговые доходы федерального бюджета собраны в размере 5352,8 млрд.руб. Значительно выросли нефтегазовые поступления и составили 3653,3 млрд.руб. По-прежнему высоки поступления по вывозным таможенным пошлинам - 2332,4 млрд.руб. Так, 384,4 млрд. руб. составили поступления по вывозным таможенным пошлинам на газ природный, следовательно, остальные 936,5 млрд.руб. составляющая вывозных таможенных пошлин на товары, выработанных из нефти.

В 2012 году неналоговые доходы бюджета выросли до 5934,5 млрд.руб. В их числе нефтегазовые неналоговые поступления исполнены в сумме 4053,1 млрд.руб. Неуклонно увеличиваются все поступления по нефтегазовым неналоговым доходам, в частности: вывозные таможенные пошлины на нефть сырую - 2489,6 млрд.руб.; вывозные таможенные пошлины на газ природный - 433,5 млрд.руб.; вывозные таможенные пошлины на товары, выработанные из нефти - 1130,0 млрд.руб.

Таким образом, за 2010-2012 гг. в федеральном бюджете Российской Федерации наибольший объем поступлений наблюдается по нефтегазовым доходам. Удельный вес нефтегазовых неналоговых доходов в общей сумме неналоговых поступлений составил: в 2010 году - 63,3\%; в 2011 году $-68,2 \%$; в 2012 году $-68,3 \%$.

На основе данных приведенных в таблице 2 изобразим рисунок, где наглядно показана динамика нефтегазовых неналоговых поступлений федерального бюджета Российской Федерации в сумме неналоговых доходов за 2010-2012 гг. (Рисунок 2). 


\section{Налоги и налогообложение - №9(111)•2013}

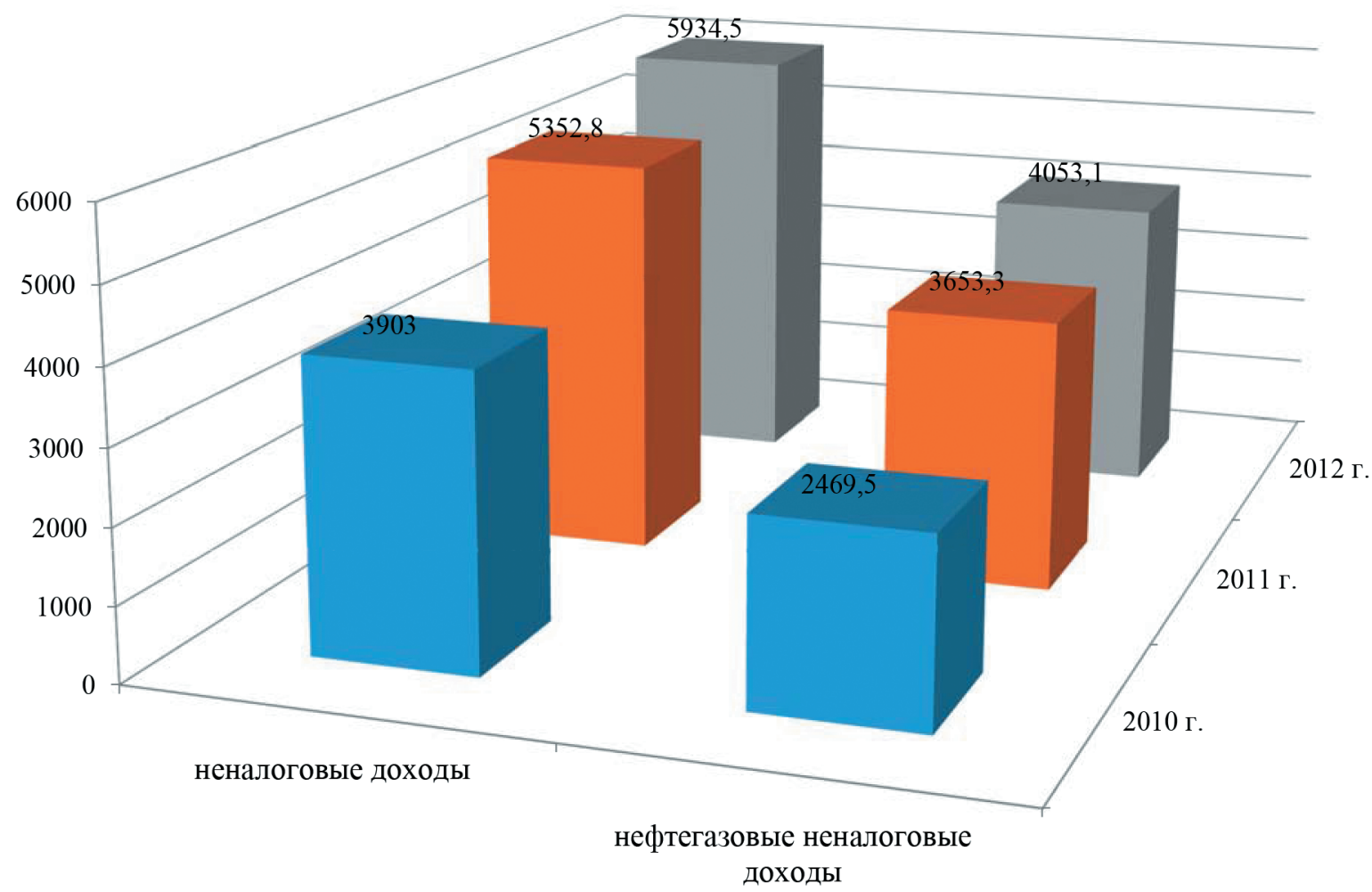

Рис. 2. Динамика нефтегазовых неналоговых доходов в федеральном бюджете Российской Федерациии за 2010-2012 г2. (млрд.руб.).

По данным рисунка 2 видно, что нефтегазовые неналоговые доходы превалируют в сумме неналоговых доходов федерального бюджета Российской Федерации за 2010-2012 гг. и имеют тенденцию к повышению. Наибольший объем в числе неналоговых доходов наблюдается по вывозным таможенным пошлинам на нефть сырую. Менее значительны поступления от вывозных таможенных пошлин на товары, выработанные из нефти. Незначительны вывозные таможенные пошлины на газ природный.

Определим роль нефтегазовых поступлений в общей системе доходов федерального бюджета РФ за 2010-2012 гг. (Таблица 3).

Таблица 3

Влияние нефтегазовых доходов на формирование федерального бюджета Российской Федерации за 2010-2012 гг. (млрд.руб.)

\begin{tabular}{|l|c|c|c|}
\hline \multicolumn{1}{|c|}{ Наименование показателя } & $\mathbf{2 0 1 0}$ г. & $\mathbf{2 0 1 1}$ г. & $\mathbf{2 0 1 2}$ г. \\
\hline $\begin{array}{l}\text { Доходы бюджета - всего } \\
\text { в том числе: }\end{array}$ & 8305,4 & 11367,2 & 12845,4 \\
\hline Нефтегазовые налоговые доходы & 1376,6 & 2007,8 & 2420,5 \\
\hline Удельный вес, \% & 16,6 & 17,7 & 18,8 \\
\hline Нефтегазовые неналоговые доходы & 2469,5 & 3653,3 & 4053,1 \\
\hline
\end{tabular}




\begin{tabular}{|l|c|c|c|}
\hline Удельный вес, \% & 29,7 & 32,1 & 31,6 \\
\hline Нефтегазовые доходы всего & 3846,1 & 5661,1 & 6473,6 \\
\hline Удельный вес, \% & 46,3 & 49,8 & 50,4 \\
\hline
\end{tabular}

Источник: Отчетные даннье об исполнении федерального бюджета Российской Федерации за 2010-2012 z2.//www.roskazna.ru.

По данным таблицы 3 видно, что за 20102012 гг. нефтегазовые доходы федерального бюджета составили: в 2010 году - 3846,1 млрд. руб.; в 2011 году - 5661,1 млрд.руб.; в 2012 году - 6473,6 млрд.руб. Их доля в системе доходов бюджета повышается. К 2012 году составила более половины всех поступлений: в 2010 году46,3\%; в 2011 году - 49,8\%; в 2012 году - 50,4\%. Причем наиболее значительны нефтегазовые неналоговые доходы. Доля неналоговых нефтегазовых доходов в общей сумме поступлений составила: в 2010 году - 29,7\% (из 46,3\%); в 2011 году - 32,1\% (из 49,8\%); в 2012 году $31,6 \%$ (из 50,4\%). Удельный вес налоговых нефтегазовых доходов менее значителен и равен: в 2010 году - 16,6\% (из 46,3\%); в 2011 году 17,7\% (из 49,8\%); в 2012 году - 18,8\% (из 50,4\%).

Таким образом, за 2010-2012 гг. нефтегазовые доходы федерального бюджета РФ формируются за счет налоговых и не налоговых поступлений: налога на добычу полезных ископаемых (нефть, газ природный); вывозных таможенных пошлин на нефть сырую; вывозных таможенных пошлин на газ природный; вывозных таможенных пошлин на товары, выработанные из нефти. Наиболее значительны неналоговые нефтегазовые поступления, а именно, вывозные таможенные пошлины на нефть сырую.

В заключение отметим, что сырьевой комплекс Российской Федерации - это серьезный рычаг, от которого зависит экономическое состояние всей экономики (все секторы экономики) и благосостояние населения государства. Нефтегазовый комплекс Российской Федерации повинен в слабости других отраслей экономики, отсутствии инноваций, неразвитости экономических институтов. В этой связи, рационально изыскать другие актуальные бюджетные резервы накопления денежных средств, причем действуя в обход нефтегазового сектора. К таким резервам можно отнести развитие малого и среднего бизнеса. Кроме того, развивать инновационную деятельность, повышать инвестиционную активность. Внедрение всех названных факторов способствует наращиванию доходов государства и снижает нефтегазовую зависимость.

\section{Библиография:}

1. Бюджетного кодекса Российской Федерации. Гл. 13.1. 2004г. [Budget code of the Russian Federation. Ch. 13.1. 2004].

2. Бюджетного кодекса Российской Федерации. Гл. 13.2. 2008г. [Budget code of the Russian Federation. Ch. 13.2. 2008].

3. Бюджетный кодекс Российской Федерации. Гл.7, ст.50. 2013 г. [Budget code of the Russian Federation. Ch. 7, art. 50. 2013].

4. Налоговый кодекс Российской Федерации. Гл. 26. 2013 г. [Tax code of the Russian Federation. Ch.26. 2013]. 
5. Федеральный закон РФ № 184-ФЗ от 10.12.2003г. «О внесении дополнений в Бюджетный кодекс РФ в части создания Стабилизационного фонда РФ»; Бюджетный кодекс РФ. Гл. 13.1. 2004 г. [The RF Federal law № 184-FZ of 10.12.2003г. «On amending the Budget code of the Russian Federation regarding the creation of the Stabilization Fund of the Russian Federation»; the RF Budget code. Ch. 13.1. 2004].

6. Федеральный закон от 26 апреля 2007 г. $\mathrm{N} 63-Ф 3$ «О внесении изменений в Бюджетный кодекс Российской Федерации в части регулирования бюджетного процесса и приведении в соответствие с бюджетным законодательством Российской Федерации отдельных законодательных актов Российской Федерации». [Federal law of 26 April 2007 N 63-FZ «On amendments to the Budget code of the Russian Federation in the part of regulation of the budget process and bringing in conformity with the budget legislation of the Russian Federation of individual legislative acts of the Russian Federation»].

7. Постановление Правительства РФ от 23.01.2004 № 31 (ред. от 21.05.2007) «Об утверждении Правил перечисления в Стабилизационный фонд Российской Федерации дополнительных доходов федерального бюджета, остатков средств федерального бюджета на начало финансового года и доходов от размещения средств Стабилизационного фонда Российской Федерации». [Resolution of the Government of the Russian Federation from 23.01.2004 № 31 (amended on 21.05.2007) «On approval of the Rules of transfer into the Stabilization Fund of the Russian Federation of additional Federal budget revenues, the rests of means of the Federal budget at the beginning of the financial year and the income from placing funds of the Stabilization Fund of the Russian Federation»].

8. Постановление Правительства РФ от 29 декабря 2007 г. № 955 «О порядке управления средствами Резервного фонда». [Resolution of the Government of the Russian Federation of December 292007 № 955 «About the order of management of the Reserve Fund»].

9. Постановление Правительства РФ от 17.12.2007 N 892 (ред. от 31.01.2009, с изм. от 21.04.2010) «О проведении расчетов и перечислении средств в связи с формированием и использованием нефтегазовых доходов федерального бюджета, нефтегазового трансферта, средств Резервного фонда и Фонда национального благосостояния» (вместе с «Правилами проведения расчетов и перечисления средств в связи с формированием и использованием в соответствии с Бюджетным кодексом Российской Федерации нефтегазовых доходов федерального бюджета, нефтегазового трансферта, средств Резервного фонда и Фонда национального благосостояния»). [Decree of the RF Government dated 17.12.2007 N 892 (amended on 31.01.2009, with MEAs. from 21.04.2010) «On the calculations and the transfer of funds in connection with the formation and use of oil and gas revenues of the Federal budget, oil and gas transfer, funds of the Reserve Fund and the national welfare Fund» (together with «Rules of settlements and enumeration funds in connection with the formation and use in accordance with the Budget code of the Russian Federation oil and gas revenues of the Federal budget, oil and gas transfer, funds of the Reserve Fund and the national welfare Fund»)].

10. Ермакова Е.А. Перспективы управления нефтегазовыми фондами России//Финансы 
и кредит.-2013.-№ 23. С. 2-10. [Ermakova E.A. Prospects of oil and gas funds-Russia//the Finance and the credit.-2013.-№ 23. P. 2-10].

11. Крюков В.А., Маршак В.Д. Нефтегазовый сектор в развитии экономики России// Регион: Экономика и Социология.-2013.-№ 2. C. 148-156. [Krjukov V.A., Marshak V.D. Oil and gas sector in Russia's economic development//Region: Economy and Sociology.-2013.-№ 2. P. 148-156.].

12. Лебединская Л. Роль нефтегазовых фондов в России//Вопросы экономики. 2012.-№3. C. 98-118. [Lebedinskaya L. Role of oil and gas assets in Russia//Voprosy Ekonomiki.-2012.-№3. P. 98-118].

13. Филимонова И.В. Финансово-экономические показатели деятельности нефтегазового комплекса России//Минеральные ресурсы России. Экономика и управление.-2012.-№ 5. С. 45-53 [Filimonova I.V. Financial and economic indicators of the oil and gas complex of Russia//Mineral resources of Russia. Economics and management. 2012. - № 5. Р. 45-53].

14. Эдер Л.В., Филимонова И.В. Экономика нефтегазового сектора России//Вопросы экономики.-2012.-№ 10. С. 76-91.[Eder L.V., Filimonova I.V. Economics and gas sector of Russia//Voprosy Ekonomiki. 2012. - № 10. P. 76-91].

15. www.roskazna.ru.

16. Агузарова Ф.С. Некоторые вопросы модернизации налоговой системы Российской Федерации // NB: Финансовое право и управление. - 2013. - 2. - С. 24 - 44. URL: http://www.e-notabene.ru/flc/article_629.html

\section{References (transliteration):}

1. Ermakova E.A. Perspektivy upravleniya neftegazovymi fondami Rossii//Finansy i kredit.-2013.-№ 23. S. 2-10. [Ermakova E.A. Prospects of oil and gas funds-Russia//the Finance and the credit.-2013.-№ 23. P. 2-10].

2. Kryukov V.A., Marshak V.D. Neftegazovyi sektor v razvitii ekonomiki Rossii//Region: Ekonomika i Sotsiologiya.-2013.-№ 2. S. 148-156. [Krjukov V.A., Marshak V.D. Oil and gas sector in Russia's economic development//Region: Economy and Sociology.-2013.-№ 2. P. 148-156.].

3. Lebedinskaya L. Rol' neftegazovykh fondov v Rossii//Voprosy ekonomiki. - 2012.-№3. S. 98118. [Lebedinskaya L. Role of oil and gas assets in Russia//Voprosy Ekonomiki.-2012.-№3. P. 98-118].

4. Filimonova I.V. Finansovo-ekonomicheskie pokazateli deyatel'nosti neftegazovogo kompleksa Rossii//Mineral'nye resursy Rossii. Ekonomika i upravlenie.-2012.-№ 5. S. 45-53 [Filimonova I.V. Financial and economic indicators of the oil and gas complex of Russia// Mineral resources of Russia. Economics and management.-2012.-№ 5. P. 45-53].

5. Eder L.V., Filimonova I.V. Ekonomika neftegazovogo sektora Rossii//Voprosy ekonomiki.-2012.-№ 10. S. 76-91.[Eder L.V., Filimonova I.V. Economics and gas sector of Russia// Voprosy Ekonomiki.-2012.-№ 10. P. 76-91].

6. Aguzarova F.S. Nekotorye voprosy modernizatsii nalogovoi sistemy Rossiiskoi Federatsii // NB: Finansovoe pravo i upravlenie. - 2013. -2. -C. 24-44. URL: http://www.e-notabene. ru/flc/article_629.html 